\title{
The Impact of Social Responsibility on Corporate Performance:
}

\section{Evidence from Taiwan}

\author{
Li-Chuan Chou ${ }^{1}$, Ta-Cheng Chang ${ }^{2}$, John Darcy ${ }^{3} \&$ Yun-Chia Yan ${ }^{3}$ \\ ${ }^{1}$ Department of International Business, National Taipei College of Business, Taipei, Taiwan \\ ${ }^{2}$ Department of International Business, Soochow University, Taipei, Taiwan \\ ${ }^{3}$ School of Accountancy, University of Texas Rio Grande Valley, Edinburg, USA \\ Correspondence: Yun-Chia Yan, School of Accountancy, University of Texas Rio Grande Valley, Edinburg, USA.
}

Received: March 21, 2017

Accepted: April 25, 2017

Online Published: April 28, 2017

doi:10.5430/afr.v6n2p181

URL: https://doi.org/10.5430/afr.v6n2p181

\begin{abstract}
Prior studies show a mixed relation between corporate social responsibility (CSR) and corporate financial performance (CFP). This paper attempts to address the issue using listed companies from Taiwan during the period from 2007 to 2010. Unlike prior studies that use qualitative approaches to construct a CSR index, this study examines the relation between CSR and CFP by directly adopting the CSR score from the CSRHub database of companies' social, environmental, and governance performance which measures these factors using a scale from zero to 100 points. We find that (1) there is a positive and significant interaction between CSR and CFP, (2) high score CSR firms tend to outperform low score CSR firms and (3) the governance dimension of CSR has a more significant and positive association with stock price returns than other dimensions (community, employees, and environment) of CSR. Our results, therefore, provide additional information regarding the relation between CSR and CFP within the context of emerging markets.
\end{abstract}

Keywords: Corporate social responsibility, Corporate financial performance, Zero-investment portfolio

\section{JEL Classification codes: G32, G34}

\section{Introduction}

Companies throughout the world are showing increased interest in demonstrating corporate social responsibility (CSR) through the issuance of CSR reports. As of 2011, it was estimated that more than half of the Fortune 1000 companies and 95\% of the world's largest 250 companies issued CSR reports (KPMG 2011).

As noted in KPMG (2011):

Clearly, corporate social responsibility (CR) reporting is now an essential requirement for any company hoping to be seen as a responsible corporate citizen. Innovation and learning, in particular, has consistently ranked highly as a driver for corporate responsibility reporting over the past decade. This is indicative of the large number of companies that see CR as a means to drive greater innovation through their businesses and products in order to create a discernable competitive advantage in the market.... With almost half of the largest companies already demonstrating financial gains from their $C R$ initiatives, and with the increasing importance of innovation and learning as key drivers for reporting, it is clear that CR has moved from being a moral imperative to a critical business issue.

Although it is recognized that that companies can obtain financial gains in practice from their CSR initiatives, prior studies into the relation between CSR and corporate financial performance (CFP) generally show that there is a mixed relation between CSR and CFP. Brine et al. (2007) examine the relation between CSR and CFP in a sample of Australian firms where separate sustainability disclosures beyond what is required by the regulatory framework is used as a proxy for whether the company is demonstrating CSR and accounting statement returns on assets, returns on equity and returns on sales are used to represent CFP. Their results fail to show a significantly measureable relationship between CSR and CFP.

Employing the Granger causality approach, Makni et al. (2009) examine the relation between CSR and CFP in Canadian firms using CSR data from the Canadian Social Investment Database for the years 2004 and 2005. Their 
results for the most part fail to show a significantly measureable relationship between CSR and CFP but, using several individual measures of CSP, find a significant negative relationship between the environmental dimension of CSP and return on assets, return on equity, and market returns. The authors observe that these results support the "negative synergy hypothesis," that socially responsible firms experience reduced shareholder wealth. Busch and Hoffmann (2011) examine the issue of the relation of CSR to CFP using a questionnaire regarding carbon emissions and carbon management strategies used by the 2,500 largest companies by market capitalization in the Dow Jones Global Index. Their results show positive relations between carbon emissions as an outcome-based measurement and CFP, but negative relations between carbon management as a process-based measurement and CFP. Choi et al. (2010) study the relationship between CSR and CFP in Korea by using a sample of 1122 firm-years during 2002-2008. Based on the data from Korea Economic Justice Institute (KEJI), they construct two CSR indexes: the equal-weighted (EW) CSR index and the stakeholder-weighted (SW) CSR index. Their results fail to demonstrate a significant relationship between the EW CSR index and CFP, but do show a significant positive relation between the SW CSR index and CFP.

By constructing a composite CSR score based on five different dimensions from the Kinder, Lydenberg, Domini Research \& Analytics (KLD) database, Scholtens (2008) examines the relationship between CSR and CFP using lagged OLS and Granger causation models in a sample of 289 firms from U.S. during the period 1991-2004. Results from their three lags model indicate that the financial returns of the firm do evidence Granger causation derived from the firm's social strengths. However results from their five lags model show that there is bidirectional Granger causation between CSR and financial return. The author attributes the mixed results to issues resulting from the model design.

Table 1 summarizes results from prior literatures regarding the relationship between CFP and CSR. The majority of the literature tends to show positive relationships between CFP and CSR, but a substantial part of the literature finds that the relation between CSR and CFP is either negative or that there is no significant relation between CSR and CFP.

Table 1. Summary Literature Review Regarding The Relation between CSR and CFP

\begin{tabular}{lrrr}
\hline & Positive & Negative & $\begin{array}{r}\text { No effect/ } \\
\text { Inconclusive }\end{array}$ \\
\hline Cochran and Wood(1984) & 9 & 1 & 3 \\
Pava and Krausz(1996) & 12 & 1 & 8 \\
Moore(2001) & 33 & 20 & 9 \\
Beurden and Gossling(2008) & 23 & 2 & 9 \\
\hline
\end{tabular}

* Cochran and Wood caution that these positive results should be "viewed with suspicion" as the result of shortcomings in the use of proxies, small sample sizes, and methodology problems.

Since results from prior studies show a mixed relation between CSR and CFP, another stream of research is trying to explain why there is a mixed result between CSR and CFP. Their findings suggest that omitting certain control variables in the design of research models contributes to the mixed results. For example: McWilliams and Siegel (2000) suggest that the mixed results between CSR and CFP are mostly due to omitting a R\&D variable in the research model. They use the Domini 400 Social Index (DSI 400) from KLD as the proxy of CSR with a dummy variable value of 1 if the company is listed on DSI 400 index; 0 otherwise. They find that there is a significant and positive relation between CSR and CFP when R\&D is not included in the mode, but no significant relation when R\&D is included in the model. On the other hand, Orlitzky (2001) hypothesized that firm size could interact with CSR and CFP simultaneously. The Orlitzky paper uses a path-analytic approach to analyze the results of a meta-analysis of observed correlations among firm size, CSR and CFP with results showing that firm size does not confound the significant positive relationship between CSR and CFP in the model.

A lacking of unanimity of CSR measurement might also contribute to the mixed results seen in prior studies regarding the relation between CSR and CFP. For example, some studies, such as Bowman and Haire (1975), define CSR by using categorical variable or dummy variable $(0,1)$ approaches where a company is considered a CSR company if its CSR policy is disclosed in the annual statement. Cochran and Wood (1984) define a company as a CSR company if the company is listed on the combined Moskowitz Reputation Index as used by Sturdivant and Ginter (1977). McWilliams and Siegel (2000) define a company as a CSR company if the company is listed on the DSI 400. Simpson and Kohers (2002) use the CRA (The Community Reinvestment Act of 1977) rating, a 12-factor 
score designed to measure how well a bank serves its community, as the proxy of a CSR dummy variable with a value of 1 if the CRA rating is outstanding and 0 otherwise. Chih et al.(2010) consider a company as a CSR company if it is listed in the Dow Jones Sustainability World Index (DJSI World). Brine et al. (2011) define a company as a CSR company if it has made separate sustainability disclosures beyond what is required of them by the regulatory framework. Other studies use weighted average approaches to construct the CSR index. For example, Choi et al. (2010) construct two CSR indexes: the equal-weighted (EW) CSR index and the stakeholder-weighted (SW) CSR index. Scholtens (2008) constructs a composite CSR score based on five dimensions from KLD database. However, the above studies all use qualitative approaches to contract CSR index. The major drawback of using a qualitative CSR index is that one cannot observe the degree of CSR among same category/level CSR companies.

The present study proposes that the financial performance of a company is associated with the degree of the company's social responsibility. In other words, we suggest that even among the same category/level CSR companies, high score CSR companies should outperform low score CSR companies. Results from prior studies were generally not able to address this issue because models based on of qualitative CRS indexes are not able to discriminate between high and low score CSR companies.

Contrary to prior studies (e.g., Bowman and Haire 1975; Cochran and Wood 1984; McWilliams and Siegel 2000; Simpson and Kohers 2002; Chih et al. 2010; Choi et al. 2010; Scholtens 2008) which use qualitative approaches to construct the CSR index, this study adopts the CSR score with a scale from zero to 100 points from the CSRHub database which ranks companies performance in four major CRS dimensions: community, employees, environment, and governance. Using the CSR score we examine the relation between CSR and CFP in a sample of 85 companies in Taiwan during the period from 2007 to 2010. Our results show that (1) there is a positive and significant interaction between CSR and CFP, (2) high score CSR firms outperform low score CSR firms, and (3) the governance dimension of CSR has more significant and positive association with stock price returns than the community, employees, and environment dimensions of CSR. Our results, therefore, provide additional insights into the relation between CSR and CFP, particularly in the context of emerging markets.

Lin et al. (2009) also examined the association between CSR and CFP in the context of Taiwanese firms. The differences between Lin et al. (2009) and our study are: (1) Lin et al. (2009) subjectively defined companies that exceed the average donation ratio in a manufacturing industry or a non-manufacturing industry as "higher-CSR firms" and those under the average donation ratio as "lower-CSR firms." Our study directly adopts the CSR score with a scale from zero to 100 points from the CSRHub database of companies' social, environmental, and governance performance. Also, Lin et al. (2009) examine a sample of 33 Taiwan-based companies over the period from 2002 to 2004. Our study looks at a considerably larger sample, 85 Taiwanese firms, over the sample period from 2007 to 2010 .

The paper proceeds as follows. Section 2 describes the sample information obtained from CSRHub database of companies' CSR performance and presents methodology used in our tests which are based on a time series regression model. Section 3 presents the empirical results from tests based on the aggregate four-dimension (community, employees, environment and governance) CSR score. Section 4 presents analysis and empirical results for tests based on the individual dimensions of the CSR score and also presents results from tests where different CSR cut-off points are employed. Section 5 presents our conclusions and implications for future research.

\section{Methodology and Data}

\subsection{Social Performance}

We test the interaction between CSR and CFP by using a sample of 85 Taiwan companies obtained from CSRHub. CSRHub is a corporate social responsibility ratings tool released in January 2011 that aggregates data from more than 100 sources and constructs corporate CSR scores for approximately 5,000 publicly traded companies from 65 countries and 135 industries around the world. In the scoring process, CSRHub rates firms according to the following four dimensions: (1) community, (2) employees, (3) environment, and (4) governance. An overview of the criteria in each dimension is provided in Appendix. For each dimension, ratings are established on a 100-point scale and companies that meet the norm would score 50 points (on a 0 to 100 scale), while those that exceed the norm would be rated higher and those who do not meet the norm would be rated lower. The ratings for each dimension are combined to produce the weighted average overall rating (overall CSR score) for a company.

Table 2 presents CSR ratings for five Asian countries. Taiwan scores second from the least among these five countries. The result illustrates the relatively low level of corporate social responsibility of Taiwan companies when measured by international standards of CSRHub. 
Table 2. Corporate Social Responsibility Rating for 5 Asian Countries

\begin{tabular}{lll}
\hline Region & Companies & Rating \\
\hline China & 80 & 42 \\
Hong Kong* & 104 & 43 \\
Japan & 459 & 47 \\
South Korea & 96 & 49 \\
Taiwan & $88^{* *}$ & 43 \\
\hline
\end{tabular}

This table presents the average overall rating for five Asian countries and regions evaluated by CSRHub. Average ratings are computed for the July 2011 evaluation.

* Hong Kong is a Special Administrative Region of the People's Republic of China.

** CSRHub constructed ratings for 88 Taiwan companies. One company was merged, another one was acquired and the other was listed in the Shenzhen stock exchange (China). As a result of removing 3 firms, there are 85 firms in our sample.

\subsection{Financial Performance}

In order to examine whether high score CSR firms outperform low score CSR firms in a comparable manner, we use a zero investment portfolios strategy that compares the differences in risk-adjusted returns associated of a portfolio of long positions in high score CSR firms with a portfolio of short positions in low score CSR firms. Based on Fama and French $(1992,1993)$, we estimate the following time series regression for the zero-investment portfolios:

$$
R_{G t}-R_{B t}=\alpha+\beta_{1}\left(R_{m t}-r_{f t}\right)+\beta_{2} S M B_{t}+\beta_{3} H M L_{t}+\varepsilon_{t}
$$

where $R_{\mathrm{Gt}}$ are the returns from the high score CSR portfolios in month $\mathrm{t}$, and $R_{\mathrm{Bt}}$ are the returns from the low score CSR portfolios in the same month. Market returns are indicated as $R_{m}$, and the risk-free rate, as represented by the Bank of Taiwan 1-month time deposit rate, is indicated as $r_{\mathrm{ft}}$.

Fama and French (1993) provide evidence using a three factor model that there are risk factors in stock returns related to size and book-to-market values of firms. Our size zero investment portfolios addresses the size effect through the inclusion of the "small minus big" variable, $S M B_{\mathrm{t}}$, which represents the spread between small and large firms based on market capitalization. The book-to-market effect is accounted for in our zero-investment portfolios using the "high minus low" variable, $H M L_{\mathrm{t}}$, which represents the spread in returns between high and low book-to-market value firms based on market capitalization. The constant term $(\alpha)$ measures the out- or underperformance of the high and low score portfolios corrected for the factors in the model. The data used to construct the three factors described above are obtained from the Taiwan Economic Journal (TEJ) database.

To calculate our measure of excess market returns $\left(R_{m t}-r_{\mathrm{ft}}\right)$, we used market returns on 85 stocks $^{1}$ listed on the Taiwan Stock Exchange reduced by the Bank of Taiwan 1-month time deposit rate. SMB is the difference in returns from a portfolio of companies with the smallest $33 \%$ of returns and a portfolio of companies with the largest $33 \%$ of returns. For the $H M L$ factor, all stocks are ranked according to book-to-market ratios. Following Fama and French $(1992,1993)$, we assign the top $33 \%$ of market capitalization to the high book-to-market portfolio and the bottom $33 \%$ to the low book-to-market portfolio and construct HML by subtracting the low from the high book-to-market returns.

\section{Empirical Results}

Before we investigate the performance of different CSR score firms, it is necessary to explain the approach that we follow. We adopt the CSRHub ratings and extend the data set backwards, assuming that corporate social responsibility ratings remain relatively stable over time. Preston and O'Bannon (1997) find that the reputation ratings (e.g., CSR rating) for individual companies change slowly over time and the correlation between individual ratings from year to year is typically 0.9 or better. Based on Preston and O'Bannon (1997), we assume that companies' CSR scores will not change significantly over time. Although this assumption introduces "look-ahead" and "survivorship" biases, the assumption is necessary before we conducting any meaningful analysis. We then collect monthly stock return data from January 2007 to December 2010 of all the Taiwan companies listed in CSRHub database. Stock return data is obtained from the Taiwan Economic Journal (TEJ) database. 
In order to measure performance, we create equally weighted portfolios based on the overall rating. We construct a good corporate social responsibility portfolio that includes firms with the highest CSR scores and a bad corporate social responsibility portfolio that includes firms with the lowest CSR scores. These portfolios are first constructed by selecting firms within 5\% and $10 \%$ cut-off points for the highest and lowest CSR score companies. However, because any analysis of the performance of ranking-based portfolios may be sensitive to the selected cut-off points (i.e., the percentage of firms in the good and bad categories), we include sensitivity tests using various additional cut-off points (i.e., $5 \%, 10 \%, 15 \%, 20 \%, 25 \%, 30 \%, 35 \%, 40 \%, 45 \%$ ).

Table 3 provides descriptive statistics for our sample firms. We observe large differences between the highest and lowest ratings for overall CSR scores and for the four dimensions of CSR. These observations provide a strong motivation for investigating whether firms with higher CSR scores are valued higher by investors.

Table 3. Descriptive Statistics for Sample Firms

\begin{tabular}{|c|c|c|c|c|c|c|c|c|c|}
\hline & Mean & S.D. & Maximum & 75 percentile & Median 2 & percentile & Minimum & Skewness & Kurtosis \\
\hline $\bar{R}$ & $1.56 \%$ & 0.1564 & $396.77 \%$ & $8.56 \%$ & $0.46 \%$ & $-6.91 \%$ & $-67.56 \%$ & 1.7643 & 23.0185 \\
\hline$R_{\mathrm{mt}}$ & $0.59 \%$ & 0.0782 & $15.00 \%$ & $6.20 \%$ & $0.81 \%$ & $-3.46 \%$ & $-18.83 \%$ & -0.2642 & 2.7432 \\
\hline$r_{\mathrm{ft}}$ & $0.11 \%$ & 0.0006 & $0.18 \%$ & $0.17 \%$ & $0.11 \%$ & $0.05 \%$ & $0.04 \%$ & 0.0430 & 1.1443 \\
\hline SMB & $-0.93 \%$ & 0.0376 & $6.36 \%$ & $1.31 \%$ & $-1.08 \%$ & $-2.90 \%$ & $-12.46 \%$ & -0.4769 & 3.8712 \\
\hline HML & $-3.18 \%$ & 0.0344 & $7.15 \%$ & $-1.22 \%$ & $-3.51 \%$ & $-5.07 \%$ & $-10.81 \%$ & 0.2546 & 3.6622 \\
\hline Overall & 41.55 & 9.4485 & 61 & 49 & 42 & 33 & 21 & -0.1385 & 2.0644 \\
\hline Community & 44.56 & 10.2451 & 61 & 52.25 & 46 & 35 & 20 & -0.4960 & 2.2368 \\
\hline Governance & 37.80 & 8.3192 & 63 & 44 & 38 & 32 & 21 & 0.1077 & 2.8900 \\
\hline Employees & 42.12 & 8.3301 & 59 & 46.25 & 44 & 38 & 8 & -1.0944 & 5.5997 \\
\hline Environment & 41.84 & 14.2602 & 66 & 51.25 & 42 & 31.5 & 13 & -0.1716 & 2.0750 \\
\hline
\end{tabular}

$R$ represents the monthly return for the individual firm in the whole samples. CSRHub index consists of four dimensions: Community, Governance, Employees, and Environment. See Appendix for the detail overview regarding each dimension.

We then estimate Eq. (1) and compute monthly $\alpha$ 's for the period 2007-2010 using the 5\% and 10\% cut-off points for high and low CSR score firms. The models are estimated using a long-short zero-investment strategy. For the separate portfolios of good and bad CSR firms the dependent variable in Eq. (1) is modified to include only the excess returns of the good CSR $\left(R_{\mathrm{Gt}}-r_{\mathrm{ft}}\right)$ and bad CSR firms $\left(R_{\mathrm{Bt}}-r_{\mathrm{ft}}\right)$ respectively.

Table 4 presents the results for the regressions of the model represented by Equation (1) with significance represented by $t$-values included for a zero-investment (Good-Bad) strategy (i.e., long investments in a portfolio of high CSR score firms and short investments in a portfolio of low CSR score firms) for portfolios using 5\% and 10\% cut-off points. In addition, results are provided for portfolios with only high score SCR firms (Good) and low score SCR firms (Bad). The first row in Table 4 presents the results for the 10\% cut-off point (Good-Bad portfolio) during 2007-2010. We find that high score CSR firms significantly outperform low score CSR firms at the $10 \%$ level, with a monthly outperformance rate $(\alpha)$ of $1.6 \%$ (or $19.2 \%$ a year). This is consistent with Choi et al. (2010) who find a positive association between CSR and CFP.

The estimates from the model reveal some further features related to the outperformance companies of the Good-Bad strategy for the $10 \%$ cut-off points. First, when comparing $\alpha$ of the zero-investment strategy with the $\alpha$ 's for the separate portfolios, we find that the outperformance of the Good-Bad strategy is attributable to the outperformance of high score CSR firms. Although $\alpha$ is negative for low score firms, it is not statistically significant. Second, we find a significant negative relationship between the Good-Bad strategy and the SMB variable. We also find a significant negative coefficient for the portfolio of high score CSR firms and a significant positive coefficient for low score CSR firms, indicating that low score CSR firms tend to be smaller. However, for the HML variable, high score CSR firms tend to have higher book-to-market values than low score CSR firms. The importance of these variables in the zero-investment strategy is highlighted by the adjusted $\mathrm{R}^{2}$ reported in the last column, which indicates that $33.72 \%$ of the performance of this strategy can be explained by these variables.

To explore whether the results described above are an artifact of the chosen cut-off point, we select a 5\% cut-off point as a robustness check for our results. We report these results in the second part of Table 4. We find that the outperformance of the Good-Bad portfolio at the 5\% cut-off point is even higher than the outperformance based on the $10 \%$ cut-off point, with a monthly $\alpha$ of $4.18 \%$, or $50.16 \%$ a year, and is significant at the $1 \%$ level. Similar to the 
results at the $10 \%$ cut-off point, we find that the portfolio of high score CSR firms has a positive significantly $\alpha$, and the portfolio of low score CSR firms has a negative but insignificant $\alpha$ coefficient. In addition, in the extreme 5\% cut-off and two sub-period samples, $\alpha$ is negative and significant at the $10 \%$ level for low score CSR firms. The empirical results for the size and book-to-market effects are similar to the outcomes based on the $10 \%$ cut-off.

Table 4. Performance Regression Based on The Overall Rating

\begin{tabular}{|c|c|c|c|c|c|c|c|c|}
\hline & & & & alpha & RMRF & SMB & HML & Adj R2 \\
\hline \multirow[t]{3}{*}{ Overall } & $10 \%$ cut-off & $2007-2010$ & Good-Bad & $\begin{array}{r}0.016^{*} \\
(1.7017)\end{array}$ & $\begin{array}{r}-0.2931 * * * \\
(-3.3323)\end{array}$ & $\begin{array}{r}-0.8658 * * * \\
(-4.2285)\end{array}$ & $\begin{array}{r}0.6015 * * * \\
(2.6788)\end{array}$ & $33.72 \%$ \\
\hline & & & Good & $\begin{array}{l}0.0097 * \\
(1.8336)\end{array}$ & $\begin{array}{r}0.8797 * * * \\
(17.7408)\end{array}$ & $\begin{array}{l}-0.2145^{*} \\
(-1.8581)\end{array}$ & $\begin{array}{r}0.2813 * * \\
(2.2217)\end{array}$ & $87.66 \%$ \\
\hline & & & $\mathrm{Bad}$ & $\begin{array}{r}-0.0063 \\
(-0.7129)\end{array}$ & $\begin{array}{r}1.1728^{* * * *} \\
(14.2316)\end{array}$ & $\begin{array}{r}0.6513 * * * \\
(3.395)\end{array}$ & $\begin{array}{r}-0.3203 \\
(-1.5223)\end{array}$ & $81.37 \%$ \\
\hline \multirow[t]{3}{*}{ Overall } & $5 \%$ cut-off & $2007-2010$ & Good-Bad & $\begin{array}{r}0.0418^{* * * *} \\
(2.8726)\end{array}$ & $\begin{array}{r}-0.3021 * * \\
(-2.2246)\end{array}$ & $\begin{array}{r}-0.6964 * * \\
(-2.2032)\end{array}$ & $\begin{array}{r}1.3767 * * * \\
(3.9712)\end{array}$ & $25.41 \%$ \\
\hline & & & Good & $\begin{array}{r}0.0138 * \\
(1.681)\end{array}$ & $\begin{array}{r}0.6895 * * * \\
(9.0151)\end{array}$ & $\begin{array}{r}-0.0584 \\
(-0.3282)\end{array}$ & $\begin{array}{r}0.3406^{*} \\
(1.744)\end{array}$ & $64.75 \%$ \\
\hline & & & $\mathrm{Bad}$ & $\begin{array}{r}-0.0187 \\
(-1.5172)\end{array}$ & $\begin{array}{r}1.0956^{* * * *} \\
(9.4992)\end{array}$ & $\begin{array}{r}0.9316^{* * * *} \\
(3.4697)\end{array}$ & $\begin{array}{r}-0.4469 \\
(-1.5175) \\
\end{array}$ & $66.83 \%$ \\
\hline
\end{tabular}

Portfolios are equally weighted and constructed the indicated cut-off points. The sample period is from 2007 to 2010. Results are reported for portfolios with $10 \%$ and 5\% cut-off points. Results are reported for Good-Bad, Good and Bad portfolios. Alpha is the monthly rate of returns. RMRF refers to the coefficient for the market risk of the portfolio $\left(R_{m t}-r_{\mathrm{ft}}\right)$, SMB refers to the coefficient for the size factor and HML to the coefficient for the book-to-market value factor. All coefficients are reported with $t$-statistics in parentheses. Significance is indicated by $*, * *$, and $* * *$ for the $10 \%, 5 \%$ and $1 \%$ level respectively.

\section{Additional Analysis}

As discussed above, CSRHub provides four separate corporate social responsibility dimensions: (1) community, (2) governance, (3) employees, and (4) environment. Using the indices for the various dimensions, we further analyze the effect of each of the dimensions of CSR on firm performance.

Table 5 presents the results for the Good-Bad investment strategy (10\% cut-off point) for all four corporate social responsibility dimensions. As seen in Table 5, the overall CSR rating leads to a significant outperformance. For the other categories, the results are mixed. We find no significant outperformance for the community, employees or environment dimensions. But the governance dimension has a significant outperformance result.

Table 5. Performance Regression Based on The Rating of Various CSR Dimensions

\begin{tabular}{|c|c|c|c|c|c|c|c|}
\hline \multirow{2}{*}{$\frac{\text { Good-Bad }}{10 \% \text { cut-off }}$} & & & alpha & RMRF & SMB & HML & $\overline{\operatorname{Adj} R 2}$ \\
\hline & \multirow[t]{5}{*}{$2007-2010$} & Overall & $\begin{array}{c}0.016^{*} \\
(1.7017)\end{array}$ & $\begin{array}{r}-0.2931 * * * \\
(-3.3323)\end{array}$ & $\begin{array}{r}-0.8658 * * * \\
(-4.2285)\end{array}$ & $\begin{array}{r}0.6015^{* * * *} \\
(2.6788)\end{array}$ & $33.72 \%$ \\
\hline & & Community & $\begin{array}{r}0.0133 \\
(1.1856)\end{array}$ & $\begin{array}{c}-0.331 * * * \\
(-3.1687)\end{array}$ & $\begin{array}{r}-0.7962 * * * \\
(-3.2738)\end{array}$ & $\begin{array}{r}0.3726 \\
(1.3971)\end{array}$ & $25.52 \%$ \\
\hline & & Governance & $\begin{array}{r}0.0213^{* *} \\
(2.3034)\end{array}$ & $\begin{array}{l}-0.1553^{*} \\
(-1.7977)\end{array}$ & $\begin{array}{r}-0.8606 * * * \\
(-4.28)\end{array}$ & $\begin{array}{r}0.6335 * * * \\
(2.8726)\end{array}$ & $27.83 \%$ \\
\hline & & Employees & $\begin{array}{l}0.0188^{*} \\
(1.8328)\end{array}$ & $\begin{array}{r}-0.167^{*} \\
(-1.7438)\end{array}$ & $\begin{array}{r}-0.9521 * * * \\
(-4.2714)\end{array}$ & $\begin{array}{r}0.9417 * * * \\
(3.8521)\end{array}$ & $31.07 \%$ \\
\hline & & Environment & $\begin{array}{r}0.0114 \\
(0.9585)\end{array}$ & $\begin{array}{r}-0.1809 \\
(-1.6313)\end{array}$ & $\begin{array}{r}-1.3071 * * * \\
(-5.0641)\end{array}$ & $\begin{array}{r}0.7824 * * * \\
(2.7639)\end{array}$ & $33.95 \%$ \\
\hline
\end{tabular}

This table presents results for the performance regressions for all separate CSR dimensions. Portfolios are equally weighted using a 10\% cut-off point. The sample period ranges from 2007 to 2010 . Results are reported for the Good-Bad portfolios. Alphas are monthly rate of return. RMRF refers to the coefficient for the market risk of the 
portfolio, SMB to the coefficient on the size factor and HML to the coefficient on the book-to-market value factor. All coefficients are reported with $\mathrm{t}$-statistics in parentheses. Significance is indicated by $*, * *$, and $* * *$ for the $10 \%$, $5 \%$ and $1 \%$ level respectively.

Part I of Table 6 further provides the results for the Good-Bad investment strategy based on different CSR cut-off points (ranging from 5\% to 45\%). The degree of abnormal stock price return decreases as the cut-off point of CSR increases. This result is most prominent in the Governance dimension.

Part II of Table 6 presents the results for the Good investment strategy based on different CSR cut-off points (ranging from 5\% to 45\%). All the alphas are positive in the Good investment strategy group, which suggests that the high score CSR companies experienced positive abnormal stock price returns during the period from 2007 to 2010.

Part III of Table 6 shows the results for the Bad investment strategy based on different CSR cut-off points (ranging from 5\% to 45\%). Almost all the alphas are negative in this group, suggesting that these low score CSR companies for the most part experienced negative abnormal stock price returns during the period from 2007 to 2010 .

Results for the overall CSR score are consistent with our hypothesis that there is a positive association between CSR and CFP. These results also provide evidence that high score CSR firms tend to outperform low score CSR firms. Demonstrating these associations has not possible in prior studies that depend on the use of categorical or dummy variables instead of quantitative CSR scores. In addition, results from Table 6 also show that the Governance dimension of CSR has a greater significant and positive association with stock price return than do the other dimensions (community, employees and environment) of $\mathrm{CSR}^{2}$.

Table 6. Performance Regression Based on The Different CSR Percentile Cut-Off Points for Three Portfolios

\begin{tabular}{|c|c|c|c|c|c|c|c|c|c|c|c|}
\hline & & alpha & $5 \%$ & $10 \%$ & $15 \%$ & $20 \%$ & $25 \%$ & $30 \%$ & $35 \%$ & $40 \%$ & $45 \%$ \\
\hline \multicolumn{12}{|l|}{ Part I } \\
\hline \multirow[t]{5}{*}{ Good-Bad } & $2007-2010$ & Overall & $0.0418^{* * *}$ & $0.016^{*}$ & 0.0134 & 0.0129 & 0.009 & 0.0084 & 0.0039 & 0.0049 & 0.0029 \\
\hline & & Community & 0.0149 & 0.0133 & 0.0127 & 0.0149 & 0.0109 & 0.0085 & 0.0068 & 0.004 & 0.0044 \\
\hline & & Governance & $0.045^{* * * *}$ & $0.0213^{* *}$ & $0.0176^{* *}$ & $0.0133^{*}$ & $0.0121^{*}$ & $0.0106^{* *}$ & $0.0088 *$ & 0.0077 & 0.0062 \\
\hline & & Employees & $0.0412^{* * *}$ & $0.0188^{*}$ & 0.0049 & 0.0055 & 0.0059 & 0.0072 & 0.0085 & 0.0072 & 0.0065 \\
\hline & & Environment & 0.0052 & 0.0114 & 0.0117 & 0.0086 & 0.0029 & 0.0021 & 0.0033 & 0.0033 & 0.0036 \\
\hline \multicolumn{12}{|l|}{ Part II } \\
\hline \multirow[t]{5}{*}{ Good } & $2007-2010$ & Overall & $0.0138 *$ & $0.0097^{*}$ & $0.0094 *$ & $0.0101^{* * *}$ & $0.0089 *$ & $0.0079 *$ & 0.0049 & 0.0063 & 0.0051 \\
\hline & & Community & 0.0079 & 0.0107 & 0.0103 & $0.0122^{* *}$ & $0.0087^{*}$ & 0.0078 & 0.0061 & 0.0047 & 0.005 \\
\hline & & Governance & $0.0221 * * *$ & $0.014 * * *$ & $0.0129 * * *$ & $0.011 * * *$ & $0.0098^{* * *}$ & $0.0069^{* *}$ & $0.0069 * *$ & $0.0062^{* *}$ & $0.0062 * *$ \\
\hline & & Employees & $0.0221 * * *$ & 0.0085 & 0.0043 & 0.0047 & 0.0053 & 0.0053 & 0.0064 & $0.0058^{*}$ & 0.0058 \\
\hline & & Environment & 0.0044 & 0.0068 & 0.0075 & 0.009 & 0.0072 & 0.0066 & 0.0052 & 0.0052 & 0.0061 \\
\hline \multicolumn{12}{|l|}{ Part III } \\
\hline \multirow[t]{5}{*}{$\mathrm{Bad}$} & $2007-2010$ & Overall & -0.0187 & -0.0063 & -0.004 & -0.0027 & -0.0001 & -0.0004 & 0.001 & 0.0013 & 0.0022 \\
\hline & & Community & -0.0069 & -0.0026 & -0.0024 & -0.0027 & -0.0022 & -0.0007 & -0.0007 & 0.0007 & 0.0006 \\
\hline & & Governance & -0.0229 & -0.0073 & -0.0047 & -0.0023 & -0.0023 & -0.0037 & -0.0019 & -0.0014 & -0.0012 \\
\hline & & Employees & $-0.0191 * *$ & -0.0103 & -0.0006 & -0.0008 & -0.0007 & -0.0019 & -0.0021 & -0.0014 & -0.0007 \\
\hline & & Environment & -0.0008 & -0.0046 & -0.0041 & 0.0004 & 0.0042 & 0.0045 & 0.002 & 0.0019 & 0.0024 \\
\hline
\end{tabular}

All Alpha coefficients are reported in the table. Significance is indicated by $*, * *$, and $* * *$ for the $10 \%, 5 \%$ and $1 \%$ level respectively.

\section{Conclusion}

Although it has long been considered that companies may obtain financial gains from CSR initiatives, prior studies into the relation between CSR and CFP have been inconclusive in demonstrating the relation between CSR and CFP. This paper attempts to address this issue by using a sample of 85 companies from Taiwan during 2007-2010. Contrary to prior studies (Bowman and Haire 1975; Cochran and Wood 1984 ; McWilliams and Siegel 2000; Simpson and Kohers 2002; Chih et al. 2010; Choi et al. 2010; Scholtens 2008) which use qualitative approaches to contract the CSR index, this study directly adopts CSR score (0-100 points scale) from CSRHub to examine the relation between CSR and CFP. Our results show that (1) there is a positive and significant interaction between CSR and CFP (2) high score CSR firms outperform low score CSR firms (3) Governance dimension of CSR has more significant and positive association with stock price return than do other dimensions (community, employees, environment) of CSR. Our study is subject to several limitations that are inherent in this type of research. For example, there may be omitted variables in the statistical model. Our database is CSRHub and the results may be 
specific to this dataset which tends to include larger firms. Further studies can examine the interaction between the degree of CSR and CFP in other emerging markets.

\section{References}

Beurden, P., \& Gössling, T. (2008). The worth of values - A literature review on the relation between corporate social and financial performance. Journal of Business Ethics, 82(2), 407-424. https://doi.org/10.1007/s10551-008-9894-x

Bowman, E.,and M. Haire. 1975. "A strategic posture toward corporate social responsibility." California Management Review, 18(2), 49-58. https://doi.org/10.2307/41164638

Brine, M., Brown, R. \& Hackett, G. (2007). Corporate social responsibility and financial performance in the Australian context. Economic Round-up, Autumn, 47-58.

Busch, T., \& Hoffmann, V. (2011). How hot is your bottom line? Linking carbon and financial performance. Business Society, 50(2), 233-265. https://doi.org/10.1177/0007650311398780

Chih, H. L., Chih, H.H., \& Chen, T.Y. (2010). On the determinants of corporate social responsibility: International evidence on the financial industry. Journal of Business Ethics, 93(1), 115-135. https://doi.org/10.1007/s10551-009-0186-x

Choi, J. S., Kwak, Y. M. \& Choe, C. (2010). Corporate social responsibility and corporate financial performance: Evidence from Korea. Australian Journal of Management, 35(3), 291-312. https://doi.org/10.1177/0312896210384681

Cochran, P., \& Wood, R. (1984). Corporate social responsibility and financial performance. Academy of Management Journal, 27(1), 42-56. https://doi.org/10.2307/255956

Fama, E., \& French, K (1992). The cross-section of expected stock returns. Journal of Finance, 47(2), 427-465. https://doi.org/10.1111/j.1540-6261.1992.tb04398.x

, (1993). Common risk factors in the returns on stocks and bonds. Journal of Financial Economics 33(1), 3-56. https://doi.org/10.1016/0304-405X(93)90023-5

KPMG. (2011). KPMG International survey of corporate responsibility reporting 2011. Retrieved February 24, 2017, from http://www.econsense.de/sites/all/files/Survey-corporate-responsibility-reporting-2011.pdf.

Lin, C.H., Yang, H.L., \& Liou, D.Y., (2009). The impact of corporate social responsibility on financial performance: Evidence from business in Taiwan. Technology in Society, 31(1), 56-63. https://doi.org/10.1016/j.techsoc.2008.10.004

Makni, R. Francoeur, C. \& Bellavance, F. (2009). Causality between corporate social performance and financial performance: Evidence from Canadian firms. Journal of Business Ethics, 89, 409-422. https://doi.org/10.1007/s10551-008-0007-7

Geoff, M. 2001. "Corporate social and financial performance: An investigation in the U.K. supermarket industry." Journal of Business Ethics, 34(3-4), 299-351.

McWilliams, A., \& Siegel D. ( 2000). Corporate social responsibility and financial performance: Correlation or $\begin{array}{llll}\text { misspecification? } & \text { Strategic }\end{array}$ https://doi.org/10.1002/(SICI)1097-0266(200005)21:5<603::AID-SMJ101>3.0.CO;2-3

Marc, O. 2001. "Does firm size confound the relationship between corporate social performance and firm financial performance?" Journal of Business Ethics, 33(2), 167-180. https://doi.org/10.1023/A:1017516826427

Moore, G. (2001). Corporate social and financial performance: An investigation in the U.K. supermarket industry. Journal of Business Ethics, 34(3/4), 299-315. https://doi.org/10.1023/A:1012537016969

Pava, M., \& Krausz, J. (1996). The association between corporate social-responsibility and financial performance: The paradox of social cost. Journal of Business Ethics, 15(3), 321-357. https://doi.org/10.1007/BF00382958

Orlitzky, M. (2001). Does firm size confound the relationship between corporate social performance and firm financial performance? Journal of Business Ethics, 33(2), 167-180. https://doi.org/10.1023/A:1017516826427

Preston, L.E., and O'Bannon, D.P. (1997). The corporate social-financial performance relationship: A typology and analysis. Business and Society, 36(4), 419-429. https://doi.org/10.1177/000765039703600406 
Scholtens, B. (2008). A note on the interaction between corporate social responsibility and financial performance. Ecological Economics, 68(1/2), 46-55. https://doi.org/10.1016/j.ecolecon.2008.01.024

Simpson, G., \& Kohers, T. (2002). The link between corporate social and financial performance: Evidence from the banking industry. Journal of Business Ethics, 35(2), 97-109. https://doi.org/10.1023/A:1013082525900

Sturdivant, F.D., \& Ginter, J.L. (1977). Corporate social responsiveness: Management attitudes and economic performance. California Management Review, 19(3), 30-39. https://doi.org/10.2307/41164709

\section{Appendix}

The Appendix provides a brief overview of the four corporate social responsibility dimensions from CSRHub: (1) community, (2) governance, (3) employees, and (4) environment.

\section{Community}

The Community Category covers the company's commitment and effectiveness within the local, national and global community in which it does business. It reflects a company's citizenship, charitable giving, and volunteerism. This category covers the company's human rights record and treatment of its supply chain. It also covers the environmental and social impacts of the company's products and services, and the development of sustainable products, processes and technologies.

\section{Governance}

The Governance category covers disclosure of policies and procedures, board independence and diversity, executive compensation, attention to stakeholder concerns, and evaluation of a company's culture of ethical leadership and compliance. Corporate governance refers to leadership structure and the values that determine corporate direction, ethics and performance. This category rates factors such as: are corporate policies and practices aligned with sustainability goals; is the management of the corporation transparent to stakeholders; are employees appropriately engaged in the management of the company; are sustainability principles integrated from the top down into the day-to-day operations of the company. Governance focuses on how management is committed to sustainability and corporate responsibility at all levels.

\section{Employees}

The Employees category includes disclosure of policies, programs, and performance in diversity, labor relations and labor rights, compensation, benefits, and employee training, health and safety. The evaluation focuses on the quality of policies and programs, compliance with national laws and regulations, and proactive management initiatives. The category includes evaluation of inclusive diversity policies, fair treatment of all employees, robust diversity (EEO-1) programs and training, disclosure of workforce diversity data, strong labor codes (addressing the core ILO standards), comprehensive benefits, demonstrated training and development opportunities, employee health and safety policies, basic and industry-specific safety training, demonstrated safety management systems, and a positive safety performance record.

\section{Environment}

The Environment category covers a company's interactions with the environment at large, including use of natural resources, and a company's impact on the Earth's ecosystems. The category evaluates corporate environmental performance, compliance with environmental regulations, mitigation of environmental footprint, leadership in addressing climate change through appropriate policies and strategies, energy-efficient operations, and the development of renewable energy and other alternative environmental technologies, disclosure of sources of environmental risk and liability and actions to minimize exposure to future risk, implementation of natural resource conservation and efficiency programs, pollution prevention programs, demonstration of a strategy toward sustainable development, integration of environmental sustainability and responsiveness with management and the board, and programs to measure and engage stakeholders for environmental improvement. 